\title{
Hydrologic impacts of climate and land-use change on Namnam Stream in Koycegiz Watershed, Turkey
}

\author{
M. A. Baloch $\cdot$ D. P. Ames $\cdot$ A. Tanik
}

Received: 13 June 2012/Revised: 8 May 2013/Accepted: 16 February 2014/Published online: 1 March 2014

(C) Islamic Azad University (IAU) 2014

\begin{abstract}
The effects of land-use and climate change on the hydrologic regime of the Namnam Stream in the Koycegiz Watershed, Turkey, are quantified using a hydrologic simulation modeling system under a number of real and potential scenarios. The study shows that urbanization has induced severe modification in the magnitude, frequency, and duration of extreme flow conditions. The mean annual flows increased by $5-60 \%$ due to $0.1-50 \%$ increase in impervious surfaces. Additionally, confounding climate change impacts include an increase in low flow pulses of $2 \%$ when considering a decrease in precipitation by $20 \%$ and a decrease in low flow pulses of $12 \%$ when considering a $20 \%$ increase in precipitation. The watershed system under investigation is significantly more sensitive to climate change scenarios involving additional inputs of precipitation compared with scenarios involving reductions in precipitation and that these changes are compounded in the presence of major land-use change. These results suggest the need for erosion control, nutrient
\end{abstract}

Dr. Mansoor Baloch conducted this research as a $\mathrm{PhD}$ student at Istanbul Technical University, Istanbul, Turkey and as a Visiting Researcher at Idaho State University, ID, USA.

M. A. Baloch $(\varangle) \cdot$ A. Tanik

Department of Environmental Engineering, Faculty of Civil

Engineering, Istanbul Technical University (ITU),

34469 Maslak, Istanbul, Turkey

e-mail: mansoorbaloch@gmail.com

Present Address:

M. A. Baloch

REB ModelAnalytics LLC, Atlanta, GA 30341, USA

D. P. Ames

Department of Civil and Environmental Engineering, Brigham Young University, CB 368, Provo, UT 84602, USA management and habitat conservation in light of rapid urbanization, as often typified in developing countries, and potential climate change to conserve essential watershed functions.

Keywords Hydrologic regime - Deforestation . Urbanization - Scenario analysis $\cdot$ Climate change

\section{Introduction}

Hydrologic response of a watershed is defined in terms of changes and fluctuations in the quantity and quality of water in a stream (Costa et al. 2003). This, in turn, defines the flow regime of the stream and its function within a watershed as a water resource for beneficial uses such as human consumption, agriculture, industry, recreation, and natural habitat conservation (Krasovskaia and Gottschalk 2002). The primary factors that characterize hydrologic response flow regime and water quality are land-use and precipitation regime in the watershed. Indeed, watershed precipitation regime is the driving force for hydrologic processes in stream networks (Poff et al. 2006).

The Intergovernmental Panel on Climate Change (IPCC) forecasts increases in risks of flooding and drought in different regions of the world due to climate change, and its potential hydrologic effects (Bates et al. 2008). Dore (2005) reviewed the worldwide precipitation patterns using available data and found that the changing pattern of precipitation around the world is perhaps the most critical climate change consideration. The effects of changes in precipitation trends on water quality, stream hydrologic regimes, and the watershed process hydrologic responses deserve systematic attention (Vidal and Wade 2008). 
This is particularly important in developing countries where sensitivity to climate change induced economic impacts may be high, land-use change often occurs rapidly, and data for hydrologic analyses are generally less available (Baloch and Tanik 2008). Several studies have reported impacts of climate change on the water resources of Turkey and have reported a decrease in the projected precipitation. The projected decreases in precipitation have been reported to vary from 5 to $25 \%$ (Yano et al. 2007; Fujihara et al. 2008; Evans 2009; Tayanc et al. 2009; Hemming et al. 2010). Durdu (2010) characterized the effects of climate change on water resources in the Buyuk Menderes River Basin in western Turkey based on 45 years of data (1963-2007). A decreasing long-term trend of annual precipitation was reported with precipitation amount decreasing by 6.8 and $14.4 \%$ in different parts of the watershed after 1980s. This is consistent with Tayanc et al. (2009) who report significant decreases of precipitation amounts in the western parts of Turkey. Ozkul (2009) predicts a reduction of $20 \%$ in surface water by 2030 in the Gediz and Buyuk Menderes river basins of Turkey due to climate change. In the Eastern Mediterranean Coast of Turkey, precipitation is projected to decrease by about 16-25\% during the period of 1990-2100 (Yano et al. 2007). Fujihara et al. (2008) report decreases in precipitation, evapotranspiration, and annual runoff by 25 , 9 , and $52 \%$, respectively, using dynamic downscaled data in the Seyhan River Basin in southern Turkey under IPCC's SRES-A2 scenario. Given these anticipated changes, understanding of complex climate-water relationships is clearly crucial for development of a sustainable integrated watershed management (IWM) strategy in Turkey.

Land-use and land-cover change in a watershed is perhaps the most indicative characteristic of anthropogenic intervention. It plays a complex multi-faceted role in the hydrologic cycle in modifying hydrologic response of a watershed, water quality, and flow regime of a stream (Poff et al. 2006). An increase in the annual mean discharge by $24 \%$ and high-flow season discharge by $28 \%$ have been reported as a result of extensive agriculture without a significant change in precipitation (Costa et al. 2003). It has been reported that extensive agriculture can result in an increase in nitrate and phosphorus levels (Jones et al. 2001). Similarly, livestock grazing and dairies may increase the presence of fecal bacteria (Bach et al. 2002), provoke erosion problems, and increase stream turbidity (Strunk 2003). Conversion of agricultural areas, forests, grass, and wetlands to urban areas leads to large proportional increases in land imperviousness in the form of roofs, sidewalks, roads, parking lots, and turf grass that can dramatically alter the natural hydrologic condition within a watershed (Im et al. 2003). The outcome of this alteration is typically reflected in increases in the volume and rate of surface runoff and decreases in groundwater recharge and base flow. This eventually leads to larger and more frequent incidents of local flooding, decreased base flow into stream channels during dry weather, increased water levels in lakes and wetlands, modified watershed water balance, and increased erosion of river channel beds and banks (Shirinian-Orlando and Uchrin 2007). Such modifications have profound effects on the aquatic organisms, and thus, on the natural ecological resources of the watershed system.

Recent work has focused on the evaluation of such alteration of natural regimes by human intervention and climate change (Choi 2008), characterization of the physical flow conditions for sustainable aquatic habitats, classification of regime types at local levels, and effects of land-use on hydrologic response, and diffuse pollution affecting the stream water quality (Al-Abed and Al-Sharif 2008; Choi et al. 2009). Limited research exists in Turkey regarding the effects of watershed land-use and climate change on hydrologic characteristics of the stream, and hence on the environmental stressors and the economic functions of a watershed. Albek et al. (2004) used the Hydrologic Simulation Program-Fortran (HSPF) model for the hydrologic modeling of the Seydi Suyu Watershed in Turkey. On the other hand, Goncu and Albek (2007) studied the effects of climate change on the hydrology of watersheds by modeling climate change scenarios on a hypothetical watershed with different land-use simulations using HSPF in Turkey. The present study attempts to fill this gap in the literature through modeling and exploration of decision support scenarios in the Namnam Stream subwatershed in the Koycegiz Watershed in Turkey by extending the work done by Yuceil et al. (2007), Baloch and Tanik (2009) and Baloch et al. (2011).

This study adopts a "What if?" approach to predict the effects of decision-making scenario and climate variability on the hydrologic regime in the watershed under different scenario analyses. It is based on the hypothesis that a growing economy will exert enormous pressure on the natural resources of the Koycegiz Watershed due to an increase in tourism and related activities. This may result in an increase in the number of hotels, resorts, and recreation sites resulting in a slow, yet pronounced, change in the land cover and land use of the watershed. Another potential source of enhanced economic activity might occur in the form of increased agricultural activities. However, regulatory measures declaring protected areas in the watershed have impeded this type of growth.

The main aim of this study was to analyze and discuss the results of a decision-making scenario where this protective regulatory measure is relaxed and major land-use changes in the watershed are realized. To quantify and describe the impacts of such a regulatory decision on water 
resources, the dynamic simulation characteristics of HSPF are used to model the present and future behavior of streamflow in the Namnam Stream. Specific objectives include (1) characterization of the hydrologic regime of Namnam Stream in the Koycegiz Watershed for present and future land-use changes and changes in precipitation trends and (2) identification and discussion on the decisionmaking imperatives resulting from such potential changes in land-use and precipitation regime. The research was conducted at Istanbul Technical University, Turkey, and Idaho State University, USA, between 2006 and 2009.

\section{Materials and methods}

\section{Study area}

The Koycegiz Watershed is located in the southwest of Turkey (Fig. 1) and consists of Koycegiz Lake that is connected to the Mediterranean Sea via Dalyan channels and lagoon system. The area is one of the most sensitive and vulnerable coastal regions of Turkey. Due to its ecological significance, part of the watershed has been declared as a special protection area (Gurel et al. 2005). The area is rich with a diverse array of amphibian, reptile, and mammal species.

The beaches along the lagoon system in the watershed are a nesting place for the endangered loggerhead sea turtle (Caretta caretta). Guner et al. (1996) reported that some 700 species of flowering plants, ferns, and conifers are found in the watershed. The watershed is a natural growing region for Anatolian sweet gum tree (Liquidambar orientalis), which is one of the native endemic plant species. Saygili et al. (2011) reported 42 species of water birds in and around the Koycegiz Lake that use the watershed for nesting and breeding purposes (Tumay and Brouwer 2007). The Koycegiz Lake-Dalyan Lagoon system provides habitat for a diverse fish community major source of fish species in the watershed (Akin et al. 2005; Yilmaz et al. 2006).

Apart from tourism, agriculture and fisheries are the major economic activities of the inhabitants for their livelihoods (Gurel et al. 2005). These three major functions heavily rely on the sustainability of natural resources in the watershed. Streamflow regimes have hydrologic and hydrodynamic interactions with connected lakes, and their analysis and evaluation may provide insights into unexpected hydrologic behavior, controls on lotic and lentic ecosystem processes, and guidance toward more appropriately managing watershed ecosystems (Arp et al. 2006). Therefore, it is imperative that the hydrologic behavior of the streams in the Koycegiz Watershed that feed the lake- lagoon system be characterized and analyzed for effects of upstream watershed processes and changes. Namnam Stream (Fig. 1) is one of the three major streams that feed the Koycegiz Lake (Yuceil et al. 2007).

\section{Modeling approach}

A data analysis and modeling system developed by the US Environmental Protection Agency called Better Assessment Science Integrating Point and Non-point Sources (BASINS) was used together with HSPF for the hydrologic modeling of the Namnam Stream sub-watershed. HSPF has been widely applied in watersheds with diverse geographic characteristics and is commonly used to characterize watershed processes and stream hydrology (Im et al. 2003; Ribarova et al. 2008) to evaluate the hydrologic and water quality impacts of land-use changes (Hunter and Walton 2008), and to explore effects of climate change (Albek et al. 2004).

The total area of the Namnam Stream sub-watershed is approximately $487 \mathrm{~km}^{2}$ and is divided into 4 sub-watersheds and 4 reaches. The model setup is shown in Fig. 2a. A watershed outlet was defined at the Namnam gauge station to use available flow data for the calibration and validation of the model. Flow data from the Namnam Stream gauge station on stream reach 2 (SW2-R2) of the model setup for years 1990-1994 were used as calibration data, whereas data for the years 1995-1999 were used for validation of the model. An additional simulation was carried out using the entire available dataset for the period 1990-1999. Land-use categories were condensed into 5 main categories to simplify the modeling process. Figure $2 b$ shows the types and distribution of land uses in the Namnam Stream sub-watershed. The major land-use/cover in the watershed is forest, with pasture and shrub land as the next most abundant type. Table 1 shows the areas, mean elevations, and mean slopes for the individual landuse segments along with the areas and land-use distribution for each individual sub-watershed. Geographic information system (GIS) functions provided by the open source MapWindow GIS software (Ames et al. 2008) within BASINS were used for data preparation and scenario generation, and an expert system for calibration of HSPF (HSPEXP) was used for parameter estimation for calibration of the hydrologic model. After obtaining an acceptable calibrated and validated hydrologic model, different scenarios were incorporated to study the impacts of climate and land-use changes on the hydrologic regime of the Namnam Stream. The results of the scenario analysis were used to quantify the modifications in the hydrologic regime of Namnam Stream using indicators of hydrologic alteration (IHA) software (Richter 1997). 
Fig. 1 Location of Koycegiz Watershed and Koycegiz LakeDalyan lagoon system (Baloch et al. 2011)

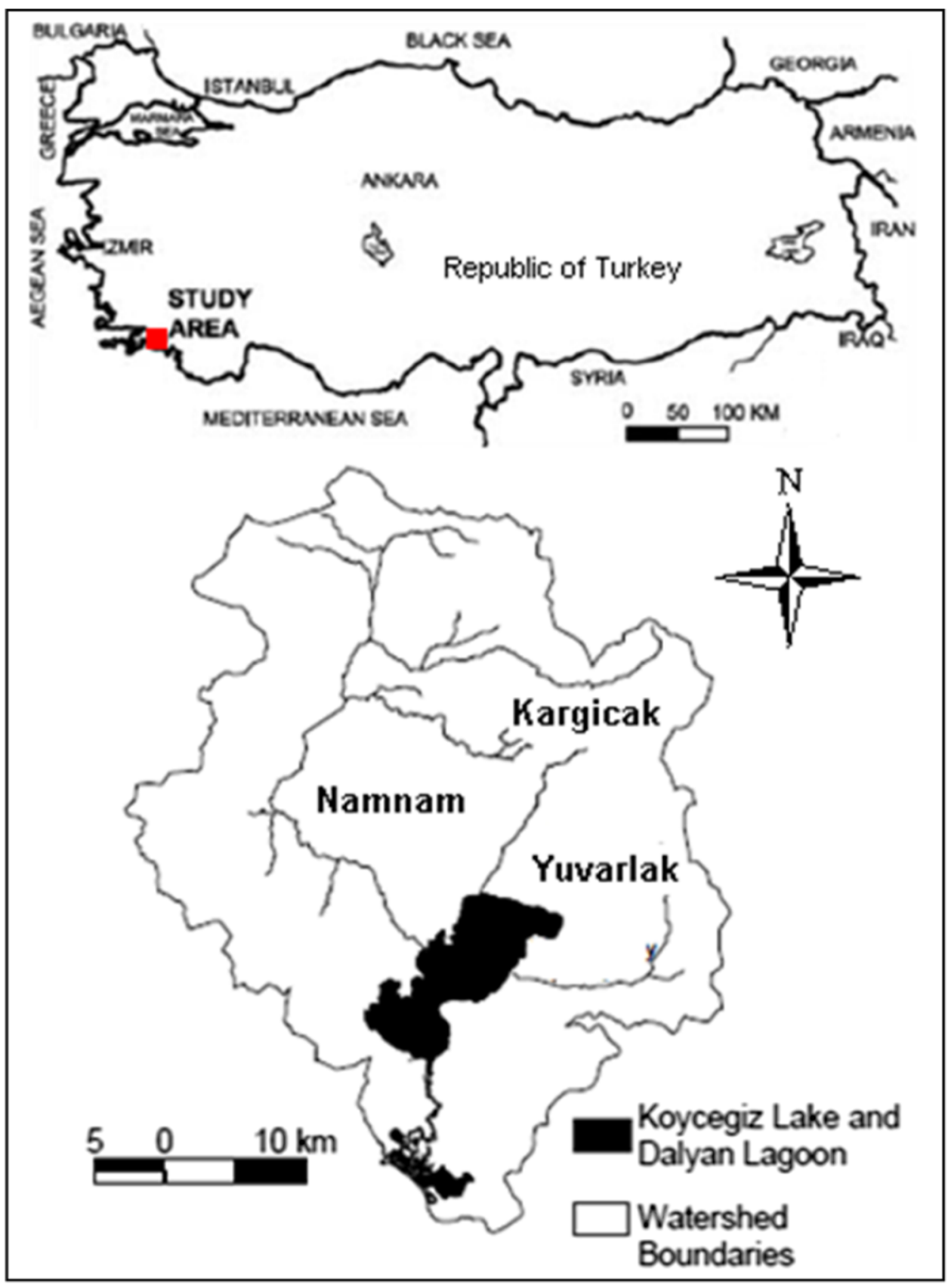

Model calibration

Calibration of HSPF is a systematic analysis of errors or differences between model simulated predictions and field observations which requires considerable effort and an expert understanding of the model processes and watershed characteristics. To overcome the difficulties of repetitive cycles of simulation, comparison, interpretation, and modification for parameter adjustment, advanced parameter estimation tools have been developed to facilitate model calibration. The HSPEXP developed by Lumb et al. (1994) was used for the determination of a single set of parameters capable of representing the entire range of flow data at Namnam gauge station. HSPEXP is an expert system that interactively allows the user to edit the input (UCI) file for HSPF, simulates the model, produces HSPF output, examines the statistics for that simulation, and provides the user with advice on which parameter should be changed to improve calibration (Lumb et al. 1994). It uses 35 rules involving over 80 conditions to recommend parameter adjustments. The rules are divided into 4 hierarchy-based ordered phases of annual volumes, low flows, storm flows, 




Fig. 2 Delineated Namnam River sub-watershed a model setup and b land use/cover

Table 1 Land-use distribution, mean elevation, and slope for delineated sub-watersheds

\begin{tabular}{|c|c|c|c|c|c|c|c|c|}
\hline Land-use segment & $\begin{array}{l}\text { SW-1 } \\
\text { Area }\left(\mathrm{km}^{2}\right)\end{array}$ & SW-2 & SW-3 & SW-4 & Total & Land dist. & $\begin{array}{l}\text { Mean elev. } \\
(\mathrm{m})\end{array}$ & $\begin{array}{l}\text { Mean slope } \\
\text { (\% rise) }\end{array}$ \\
\hline Forest & 46 & 65 & 53 & 228 & 393 & 80.6 & 751.48 & 27.22 \\
\hline Agriculture & 8 & 1 & 1 & 0 & 11 & 2.3 & 106.44 & 2.3 \\
\hline Pasture & 13 & 6 & 20 & 4 & 43 & 8.92 & 721.09 & 18.18 \\
\hline Shrub land & 18 & 6 & 2 & 0 & 25 & 5.22 & 500.73 & 14.71 \\
\hline Orchards & 6 & 0 & 0 & 0 & 6 & 1.2 & 9.75 & 0.28 \\
\hline Others (water, wetlands) & 1 & 2 & 3 & 2 & 9 & 1.76 & 183.96 & 3.7 \\
\hline Total & 92 & 81 & 79 & 235 & 487 & 100 & 716.64 & 25.82 \\
\hline$\%$ Distribution & 19 & 17 & 16 & 48 & 100 & & & \\
\hline
\end{tabular}

and seasonal flows. The rules in individual phases are tested and, once satisfied, the system moves to the next phase. Current versions of HSPEXP have the capability of calibrating only HSPF hydrologic models, and the details of the HSPEXP criteria are given in Lumb et al. (1994).

\section{Model evaluation}

In addition to graphical methods, the performance of the model for simulating runoff was evaluated using statistical methods. The deviation of runoff volumes $\left(D_{\mathrm{v}}\right)$, the NashSutcliffe coefficient $(E)$, and the coefficient of gain from daily means or Garrick Coefficient (DG) are the three criteria recommended by ASCE (1993) to evaluate continuous flow modeling (Table 2). The deviation of runoff volumes $D_{\mathrm{v}}$, also known as the percentage bias, is perhaps the simplest goodness-fit criterion. For a perfect model, $D_{\mathrm{v}}$ is equal to zero. The smaller the $D_{\mathrm{v}}$ value, the better the performance of the model. The Nash-Sutcliffe coefficient, $E$, is a measure of statistical association, which indicates 
Table 2 Model efficiency criteria for the assessment of model performance

\begin{tabular}{lll}
\hline $\begin{array}{l}\text { Model efficiency } \\
\text { criteria }\end{array}$ & Formula & $\begin{array}{l}\text { Eq. } \\
\text { no. }\end{array}$ \\
\hline $\begin{array}{l}\text { Deviation of runoff } \\
\text { volumes }\end{array}$ & $D_{\mathrm{v}}[\%]=\frac{\sum_{i=1}^{n}(O-S)}{\sum_{i=1}^{n}(O)} \times 100$ \\
$\begin{array}{l}\text { Nash-Sutcliffe } \\
\text { coefficient }\end{array}$ & $E=1-\frac{\sum_{i=1}^{n}(O-S)^{2}}{\sum_{i=1}^{n}(O-\phi)^{2}}$ \\
$\begin{array}{l}\text { Coefficient of gain } \\
\begin{array}{c}\text { Coefficient of } \\
\text { determination }\end{array}\end{array}$ & $\mathrm{DG}=1-\frac{\sum_{i=1}^{n}(O-S)^{2}}{\sum_{i=1}^{n}(O-\tilde{\phi})^{2}}$ \\
\end{tabular}

where $O$ is the measured daily discharge, $S$ is the simulated/computed daily discharge, $\delta$ is the average simulated/computed discharge, $\phi$ is the average measured daily discharge, $\tilde{\phi}$ is the average measured discharge for each day of the period. $n$ is the number of daily discharge values

the percentage of the observed variance that is explained by the predicted data. The Nash-Sutcliffe coefficient, also known as the efficiency criterion, is frequently used in the hydrologic literature for the evaluation of model performance. The second term in Eq. 2 given in Table 2 represents the ratio between the mean square error and the variance of the measured data. Thus, a value of $E$ equal to zero indicates that the model output is not better than that obtained using the simple averaged observed streamflow for the entire period of analysis.

The Garrick coefficient, also known as coefficient of gain, is a modified form of the Nash-Sutcliffe coefficient. The difference is described in detail by Martinec and Rango (1989) and ASCE (1993). It uses daily averages from the past years included in the data period as opposed to one overall daily average for the whole time step. This, in turn, emphasizes the average flows and not the extreme flows or the seasonal variation. In addition to the three criteria recommended by ASCE (1993), the coefficient of determination, $R^{2}$, is also determined. It estimates the combined dispersion against the single dispersion of the observed and predicted series. The range of $R^{2}$ lies between 0 and 1 which describes how much of the observed dispersion is explained by the prediction. A value of 0 means no correlation at all, whereas a value of 1 indicates that the dispersion of the prediction is equal to that of the observation.

Scenario development and impact analysis

The principal land-cover feature of the Koycegiz Watershed is forests that constitute approximately $80 \%$ of the total area. Forests play a major role in sustaining the unique ecological equilibrium within the watershed.
Deforestation is a major concern in many of the watersheds, causing serious environmental and ecological problems like loss of biodiversity, increase in erosion, and climate change. Specific watershed data on deforestation rates in Koycegiz Watershed were not available, but due to its importance as an attractive tourist destination, there is a perceived risk of deforestation due to development of mass tourism facilities. Erturk et al. (2012) used remote sensing data to study the land-use changes in the Koycegiz Watershed and reported a 37 and $1 \%$ decrease in agricultural areas and forests, respectively, and a $24 \%$ increase in bare soil. They also reported that the decrease in agricultural area cannot be precisely calculated as it was difficult to distinguish deciduous tree dominated regions and some crops in the crop pattern, such as citrus fruit trees using remote sensing techniques. Their study adds to the general understanding in Turkey that forests are first converted to barren land and then within years are used as agricultural areas or for tourism facilities (urbanization). A discussion of mass tourism development and deforestation in Turkey is provided in Kuvan (2010). Land-use change scenarios were created to analyze the impacts of deforestation due to development of tourism facilities, urbanization, and increase in impervious surfaces. The direct anthropogenic alteration of watershed characteristics by deforestation, urbanization, and extensive agriculture was incorporated into land-use scenarios for analysis of their impacts on hydrologic response in the Namnam Stream sub-watershed of the Koycegiz Watershed.

Considering the importance of forests for a healthy watershed, and effects of land-use changes in the watershed, the following scenarios were created:

- L1: $25 \%$ of forests were converted into agricultural areas (deforestation, extensive agriculture)

- L2: $0.1 \%$ of forests were converted into impervious land (deforestation, urbanization)

- L3: $1 \%$ of forests were converted into impervious land (deforestation, urbanization)

- L4: $2 \%$ of forests were converted into impervious land (deforestation, urbanization)

- L5: $5 \%$ of forests were converted into impervious land (deforestation, urbanization)

- L6: $10 \%$ of forests were converted into impervious land (deforestation, urbanization)

- L7: $25 \%$ of forests were converted into impervious land (deforestation, urbanization)

- L8: $50 \%$ of forests were converted into impervious land (deforestation, urbanization)

Effects of climate change on the hydrologic response in the watershed were analyzed as changes in precipitation. Dore (2005) has reported that precipitation over Northern 
Europe has increased by $10-40 \%$ in the twentieth century, whereas some parts of Southern Europe have dried by as much as $20 \%$. These trends are consistent with the findings of Onol and Semazzi (2009) that used the regional climate model (RCM) (ICTP-RegCM3) to downscale the present and future scenario simulations generated by the NASA-Finite Volume General Circulation Model (fvGCM) over the Eastern Mediterranean Region. They reported $24-48 \%$ seasonal precipitation changes in different parts of the Eastern Mediterranean Region. Similarly, Evans (2009) examined the performance and future predictions for the Middle East Region produced by 18 global climate models (GCMs) under the Special Report on Emission Scenarios (SRES) A2 emission scenario and reported that the largest decreases in precipitation occurred over southwestern Turkey with annual decreases over $125 \mathrm{~mm}$ representing more than $25 \%$ of the current precipitation. Hemming et al. (2010) ran ensembles from two GCMs and one RCM to examine the direction and general magnitude of precipitation changes in western coastal areas of Turkey. In these areas, the median members of all three model ensembles showed decreasing future precipitation projections of between -5 and $-25 \%$. This is also consistent with projections of $20 \%$ decrease in land surface water availability due to decreasing precipitation in these areas noted in CMIP3 multi-model simulations (Mariotti et al. 2008).
To simulate the effects of climate change in the watershed, three scenarios were created that incorporate possible changes in precipitation regime due to climate change, keeping in view the predicted trends in precipitation regime. Although majority of the studies predict a 5-25\% decrease in the precipitation, for the present study, climate change scenarios were created to analyze both extreme conditions of flooding and drought. The precipitation changes were introduced in the HSPF model by creating the following scenarios:

- P1: $20 \%$ increase in precipitation

- P2: $10 \%$ decrease in precipitation

- P3: $20 \%$ decrease in precipitation

Several methods exist to evaluate the alteration in the hydrologic regime of a stream. Most of these methods fall into what are known as hydrologic indices (Richter 1997; Olden and Poff 2003). The IHA is one such frequently used method that was chosen for analyzing the alteration in the flow regime of the Namnam Stream as result of land-use and precipitation change scenarios. Selected hydrologic statistics from IHA method are used to study the impact of landuse and climate change on the hydrologic regime of the Namnam Stream. These statistics provide information on some of the most ecologically significant features of hydrologic regime of the Namnam Stream influencing aquatic, wetland, and riparian ecosystems. The IHA analysis

Table 3 HSPF calibrated parameters in comparison with other cited articles

\begin{tabular}{|c|c|c|c|c|c|c|c|c|}
\hline $\begin{array}{l}\text { Parameter } \\
\text { Description }\end{array}$ & $\begin{array}{l}\text { LZSN } \\
\text { Lower zone } \\
\text { nominal } \\
\text { storage }(\mathrm{mm})\end{array}$ & $\begin{array}{l}\text { INFILT } \\
\text { Index to soil } \\
\text { infiltration } \\
\text { capacity } \\
(\mathrm{mm} / \mathrm{h})\end{array}$ & $\begin{array}{l}\text { AGWRC } \\
\text { Groundwater } \\
\text { recession } \\
\text { coefficient } \\
\text { (day_1) }\end{array}$ & $\begin{array}{l}\text { UZSN } \\
\text { Upper zone } \\
\text { nominal } \\
\text { storage } \\
(\mathrm{mm})\end{array}$ & $\begin{array}{l}\text { DEEPFR } \\
\text { Fraction of groundwater } \\
\text { inflow which will enter } \\
\text { deep groundwater and be } \\
\text { lost }\end{array}$ & $\begin{array}{l}\text { LZETP } \\
\text { Lower } \\
\text { zone ET } \\
\text { parameter }\end{array}$ & $\begin{array}{l}\text { INTFW } \\
\text { Interflow } \\
\text { inflow } \\
\text { parameter }\end{array}$ & $\begin{array}{l}\text { IRC } \\
\text { Interflow } \\
\text { recession } \\
\text { parameter }\end{array}$ \\
\hline This study & $53.34-112$ & 20.32 & $0.85-0.91$ & $30.48-35.56$ & $0.2-0.5$ & $0.1-0.7$ & $1.0-8.0$ & $0.2-0.4$ \\
\hline $\begin{array}{r}\text { Im et al. } \\
(2003)\end{array}$ & $109.22-147.32$ & $1.1938-1.905$ & $0.88-0.91$ & $8.89-25.4$ & $0.05-0.45$ & $0.2-0.7$ & $1.0-1.7$ & $0.3-0.5$ \\
\hline $\begin{array}{l}\text { Albek et al. } \\
(2004)\end{array}$ & 80 & 20 & 0.99 & 15 & 0.35 & 0.1 & 2.0 & 0.65 \\
\hline $\begin{array}{l}\text { Saleh and } \\
\text { Du (2004) }\end{array}$ & 152.4 & 4.064 & 0.98 & 28.6512 & 0.8 & 0.6 & 2.5 & 0.5 \\
\hline $\begin{array}{c}\text { Xu et al. } \\
\text { (2007) }\end{array}$ & $3.8-5.0$ & $0.05-0.18$ & $0.92-0.98$ & $0.43-0.72$ & & $0.40-0.70$ & $3.0-2.0$ & $0.5-0.7$ \\
\hline $\begin{array}{l}\text { Shirinian- } \\
\text { Orlando } \\
\text { and } \\
\text { Uchrin } \\
(2007)\end{array}$ & $10.16-16.51$ & $1.27-2.34$ & $0.94-0.99$ & $1.45-2.16$ & $0.1-0.25$ & $0.2-0.3$ & $3.0-2.0$ & 0.9 \\
\hline $\begin{array}{l}\text { Choi and } \\
\text { Deal } \\
(2008)\end{array}$ & 203.2 & 2.79 & 0.975 & 20.3 & 0.15 & 0.2 & 1.7 & 0.7 \\
\hline $\begin{array}{c}\text { Ribarova } \\
\text { et al. } \\
\text { (2008) }\end{array}$ & 15 & $0.05-0.16$ & 0.994 & 2 & 0.15 & $0.2-0.7$ & 1.25 & 0.3 \\
\hline
\end{tabular}


Fig. 3 a Calibration standard plot for monthly simulated and observed streamflow in the Namnam River b validation standard plot for monthly simulated and observed streamflow in the Namnam River
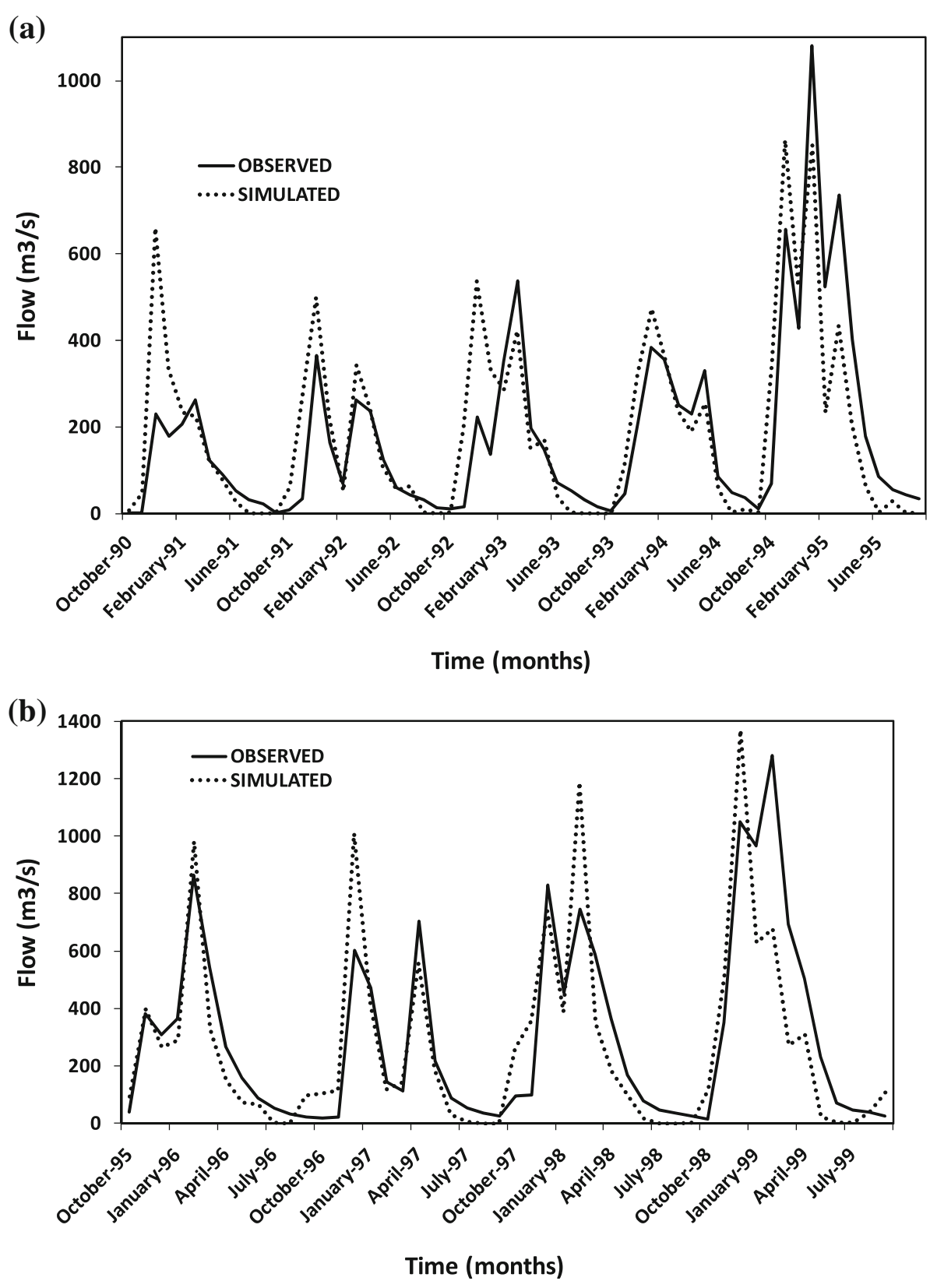

method is commonly used for the assessment of hydrologic alteration level due to a man-made or natural impact on a hydrologic regime (Richter et al. 1996). Detailed description of the method and IHA parameters and statistics are provided in Richter et al. (1996) and Olden and Poff (2003).

\section{Results and discussion}

Model calibration and validation

The hydrologic model for the Koycegiz Watershed was calibrated and validated using flow data from Namnam
Stream for the entire period 1990-1999. The final values of the hydrologic parameters that were adjusted using HSPEXP during the calibration process are listed in Table 3 together with parameter values from other studies that used HSPF as the primary hydrologic model reported in the literature. The range of values for each parameter represents the physical variations in the segmented subbasins resulting in a different parameter value for that corresponding sub-basin.

The final values of the parameters fall within the range of values reported by other modeling studies. Figure $3 a, b$ shows the graphical comparison of observed and simulated monthly flows for the calibration and validation periods, 
Fig. 4 a Calibration scatter plot for monthly simulated and observed streamflow in the Namnam River b validation scatter plot for monthly simulated and observed streamflow in the Namnam River
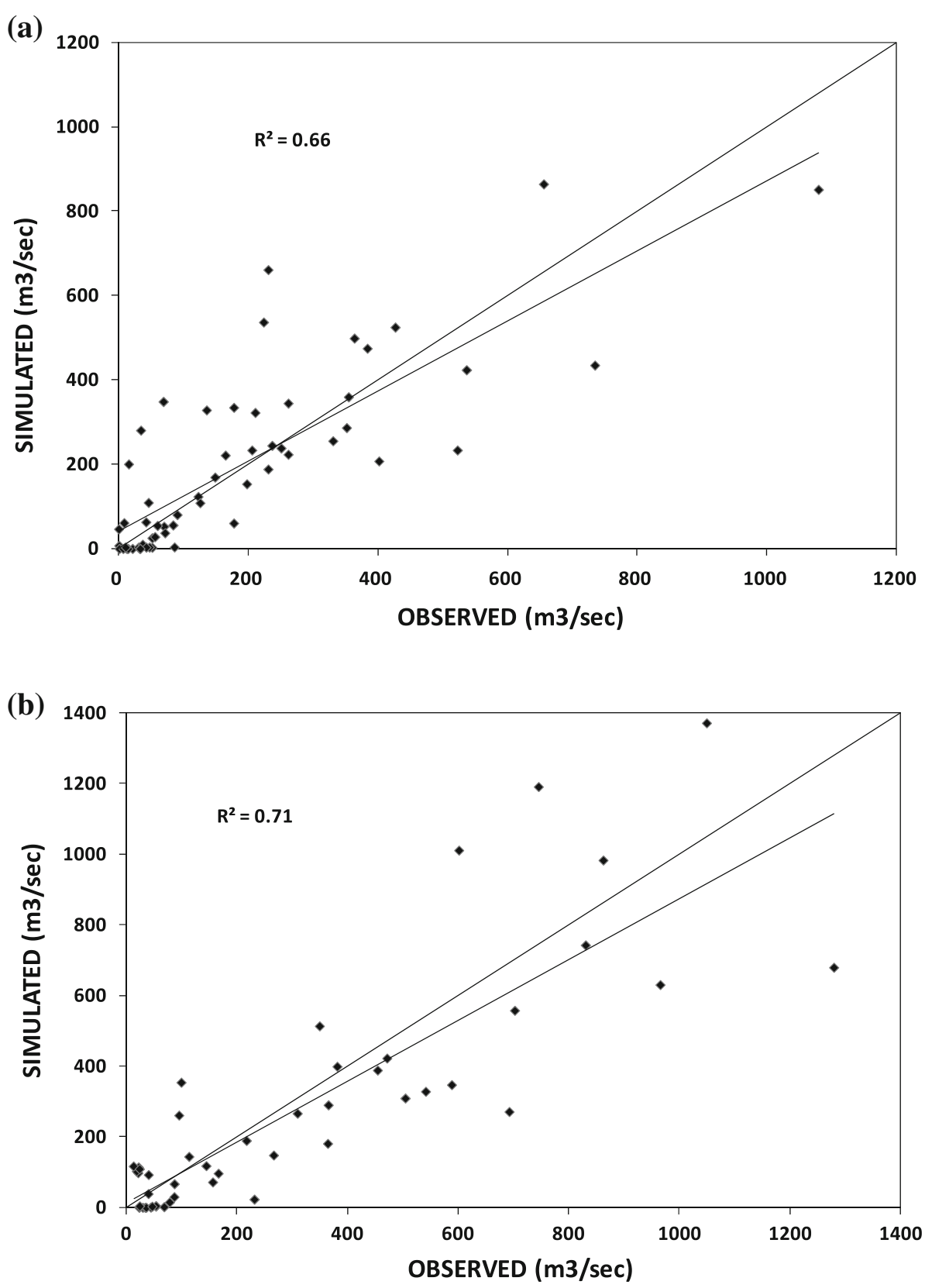

respectively. Figure 4a, b shows scatter plots for the calibration and validation periods, respectively. The model calibration and validation showed "fair" to "very good" results in the comparison with total runoff, total storm volumes, and total winter flow volumes based on HSPEXP criteria. However, summer flow volumes and the low flows were under represented by the model (Table 4).

The results of the model evaluation based on ASCE criteria are presented in Table 5. The results of model evaluation further strengthen the findings from the graphical comparison of the model results as well as the model calibration findings based on HSEXP criteria. The deviation of runoff volumes $D_{\mathrm{v}}$ can be termed fair with a range of -6.31 to $16.6 \%$ for daily flows for all the three model runs while the monthly flows exhibited a range of $2.64-9.28 \%$. Ideally, for a perfect model, $D_{\mathrm{v}}$ should be equal to zero and a smaller $D_{\mathrm{v}}$ value shows a better performance of the model. The Nash-Sutcliffe coefficient, $E$, indicates that approximately $57-59 \%$ of the observed variance in daily flows is explained by the predicted data, while it does a better job for monthly flows with values ranging from 65 to $69 \%$. The low 
Table 4 Model calibration performance based on HSPEXP criteria

\begin{tabular}{|c|c|c|c|c|c|}
\hline Flow component (units) & Simulated & Observed & $\%$ Error & Criteria & Status \\
\hline Total runoff $(\mathrm{mm})$ & 302 & 312 & -3 & $10 \%$ & Very good \\
\hline Total of highest $10 \%$ flows $(\mathrm{mm})$ & 138 & 144 & -4 & $15 \%$ & Very good \\
\hline Total of lowest $50 \%$ flows (mm) & 15 & 24 & -36 & $10 \%$ & Poor \\
\hline Evapotranspiration (mm) & 28 & 28 & 1 & $10 \%$ & Very good \\
\hline Total storm volume (mm) & 69 & 84 & -18 & $10 \%$ & Fair \\
\hline Average of storm peaks $\left(\mathrm{m}^{3} / \mathrm{s}\right)$ & 55 & 68 & -19 & $15 \%$ & Fair \\
\hline Summer flow volume (mm) & 4 & 15 & -71 & $10 \%$ & Poor \\
\hline Winter flow volume (mm) & 185 & 172 & 7 & $10 \%$ & Good \\
\hline Summer storm volume(mm) & 0 & 0 & 0 & $15 \%$ & - \\
\hline Base flow recession rate (ratio) & 1 & 1 & 0 & 0.01 & Very good \\
\hline
\end{tabular}

Table 5 Results of model efficiency criteria for the calibration and validation of HSPF hydrologic model for Namnam Stream

\begin{tabular}{|c|c|c|c|c|c|c|}
\hline \multirow[t]{3}{*}{ Criteria } & \multirow{2}{*}{\multicolumn{2}{|c|}{$\frac{\text { Calibration }}{1990-1994}$}} & \multirow{2}{*}{\multicolumn{2}{|c|}{$\frac{\text { Validation }}{1995-1999}$}} & \multirow{2}{*}{\multicolumn{2}{|c|}{$\frac{\text { Entire period }}{1990-1999}$}} \\
\hline & & & & & & \\
\hline & Daily & Monthly & Daily & Monthly & Daily & Monthly \\
\hline$D_{v}$ & -6.31 & -6.33 & 16.28 & 9.28 & 6.66 & 2.64 \\
\hline E & 0.59 & 0.65 & 0.57 & 0.69 & 0.58 & 0.67 \\
\hline DG & 0.51 & 0.78 & 0.34 & 0.82 & 0.42 & 0.80 \\
\hline $\mathrm{R}^{2}$ & 0.59 & 0.66 & 0.59 & 0.71 & 0.59 & 0.70 \\
\hline
\end{tabular}

values of $\mathrm{R}$ can be attributed to Nash-Sutcliffe statistic's emphasis on extreme events than on average flows because of its definition. Additionally, the timing of the predicted series greatly influences the value of the coefficient. Similarly the Garrick coefficient varies between 34 and $49 \%$ for daily flows and $78-82 \%$ for the monthly flows. The coefficient of determination $R^{2}$ follows a similar trend with better prediction performance for monthly flows (66-71\%) compared with that of daily flows $(59 \%)$.

\section{Hydrologic alteration}

The results of different scenarios were analyzed in terms of the effects of land-use and climate change on the hydrologic regime of the stream. The alterations in the hydrologic regime of the Namnam Stream were analyzed using the IHA method by performing an individual analysis on the flow results of each simulation. The analysis period was between years 1991-1999 of the simulated results for the reach number 2 (SW2-R2 in Fig. 2) of the watershed model network. Table 6 lists the parameters for the IHA for different land-use scenarios. The mean annual flow increased with deforestation.
However, increase in urbanization induced a more significant increase in the flow.

The mean annual flows under agriculture (L1) and the urbanization scenarios (L2, L3 and L4) increased by $5 \%$. More pronounced changes in the mean annual flows were observed for the L5 to L8 urbanization scenarios. Changes in the magnitude of monthly water conditions were more pronounced in the months of August, September, and October for all the land-use scenarios while least changes were observed for the months of April, May, June, and July for all the land-use scenarios. The extreme low flow conditions were similar for all land-use scenarios, and as the results for low flows in the hydrologic model were poor in terms of predictability, they were not considered for the IHA analysis. However, the 90-day minimum values decreased with increase in deforestation. The extreme high-flow conditions increased with rises in deforestation and imperviousness as a result of urbanization. The most pronounced change was in the one-day maximum flow value that increased from 97 to $262 \%$ as a result of deforestation and increase in impervious surfaces from 0.1 to $50 \%$ (L2L8) due to urbanization land-use scenarios. The 90-day maximum flows were increased by $7-62 \%$ for the increase in imperviousness land-use scenarios. The changes in extreme high-flow conditions varied from $7 \%$ for the 1-day maximum and 2-day maximum to $4 \%$ for the 90-day maximum flow conditions for the agricultural scenario (L1). The results are in agreement with those of Cheng and Wang (2002), Choi and Deal (2008) and Choi (2008). The timings of annual extreme flows were similar for the base scenario and the extensive agriculture scenario; however, the timings shifted from mid-July for base scenario and agriculture (L1), to beginning and mid-January for urbanization scenarios. The urbanization scenarios were characterized by higher 
Table 6 IHA analysis for the effects of land-use change on hydrologic regime of Namnam Stream

\begin{tabular}{|c|c|c|c|c|c|c|c|c|}
\hline IHA parameters & L1 & L2 & L3 & L4 & L5 & L6 & L7 & L8 \\
\hline \multicolumn{9}{|c|}{ Change in IHA parameters (percentage) } \\
\hline $\begin{array}{l}\text { Mean annual } \\
\text { flow }\end{array}$ & 5 & 5 & 5 & 5 & 10 & 15 & 25 & 60 \\
\hline \multicolumn{9}{|c|}{ Magnitude of monthly water conditions } \\
\hline October & 7 & 0 & 2 & 4 & 10 & 19 & 63 & 141 \\
\hline November & 5 & 0 & 1 & 3 & 7 & 14 & 41 & 94 \\
\hline December & 4 & 2 & 3 & 4 & 6 & 11 & 25 & 60 \\
\hline January & 3 & 0 & 0 & 1 & 2 & 5 & 15 & 38 \\
\hline February & 6 & 27 & 28 & 29 & 32 & 37 & 19 & 44 \\
\hline March & 3 & 0 & 1 & 2 & 4 & 8 & 26 & 62 \\
\hline April & 3 & 0 & 0 & 0 & 1 & 1 & 7 & 22 \\
\hline May & 2 & 0 & 1 & 1 & 3 & 6 & 22 & 58 \\
\hline June & 1 & 0 & 0 & 0 & 0 & 0 & 2 & 7 \\
\hline July & 1 & 0 & -1 & 0 & -1 & -1 & 6 & 22 \\
\hline August & 6 & 0 & 1 & 3 & 10 & 24 & 88 & 215 \\
\hline September & 5 & 1 & 3 & 6 & 15 & 30 & 88 & 203 \\
\hline \multicolumn{9}{|c|}{ Magnitude of annual extreme flows } \\
\hline $\begin{array}{l}\text { 90-day } \\
\text { minimum }\end{array}$ & 0 & 0 & 0 & 0 & -1 & -3 & -5 & -8 \\
\hline 1-day maximum & 0 & 97 & 102 & 109 & 129 & 164 & 132 & 262 \\
\hline 3-day maximum & 7 & 61 & 63 & 66 & 76 & 94 & 71 & 155 \\
\hline 7-day maximum & 7 & 37 & 39 & 41 & 46 & 58 & 49 & 117 \\
\hline $\begin{array}{l}\text { 30-day } \\
\text { maximum }\end{array}$ & 5 & 14 & 14 & 15 & 19 & 25 & 30 & 72 \\
\hline $\begin{array}{l}\text { 90-day } \\
\text { maximum }\end{array}$ & 4 & 7 & 8 & 9 & 11 & 16 & 26 & 62 \\
\hline $\begin{array}{l}\text { Number of zero } \\
\text { days }\end{array}$ & 3 & 0 & -2 & -2 & -1 & 3 & 24 & 46 \\
\hline \multicolumn{9}{|c|}{ Frequency and duration of high and low pulses } \\
\hline $\begin{array}{l}\text { Low pulse } \\
\text { count }\end{array}$ & -6 & 0 & 12 & 25 & 50 & 162 & 900 & 1443 \\
\hline $\begin{array}{c}\text { Low pulse } \\
\text { duration }\end{array}$ & 5 & 0 & -10 & -17 & -30 & -66 & -90 & -93 \\
\hline $\begin{array}{l}\text { High pulse } \\
\text { count }\end{array}$ & -5 & 1 & 5 & 11 & 45 & 116 & 192 & 213 \\
\hline $\begin{array}{l}\text { High pulse } \\
\text { duration }\end{array}$ & 23 & -1 & -4 & -9 & -29 & -52 & -65 & -66 \\
\hline
\end{tabular}

L1: $25 \%$ of forests were converted into agricultural areas (deforestation, extensive agriculture)

L2: $0.1 \%$ of forests were converted into impervious land (deforestation, urbanization)

L3: $1 \%$ of forests were converted into impervious land (deforestation, urbanization)

L4: $2 \%$ of forests were converted into impervious land (deforestation, urbanization)

L5: $5 \%$ of forests were converted into impervious land (deforestation, urbanization)

L6: $10 \%$ of forests were converted into impervious land (deforestation, urbanization)

L7: $25 \%$ of forests were converted into impervious land (deforestation, urbanization)

L8: $50 \%$ of forests were converted into impervious land (deforestation, urbanization)
Table 7 IHA analysis for the effects of climate change on hydrologic regime of Namnam Stream

\begin{tabular}{|c|c|c|c|}
\hline IHA parameters & $\mathrm{P} 1$ & $\mathrm{P} 2$ & $\mathrm{P} 3$ \\
\hline \multicolumn{4}{|c|}{ Change in IHA parameters (Percentage) } \\
\hline Mean annual flow & 25 & -10 & -25 \\
\hline \multicolumn{4}{|c|}{ Magnitude of monthly water conditions } \\
\hline October & 30 & -15 & -29 \\
\hline November & 26 & -13 & -26 \\
\hline December & 28 & -13 & -25 \\
\hline January & 20 & -10 & -21 \\
\hline February & 23 & -10 & -21 \\
\hline March & 23 & -12 & -24 \\
\hline April & 21 & -11 & -22 \\
\hline May & 22 & -12 & -24 \\
\hline June & 21 & -11 & -22 \\
\hline July & 22 & -12 & -23 \\
\hline August & 31 & -15 & -30 \\
\hline September & 28 & -13 & -25 \\
\hline \multicolumn{4}{|c|}{ Magnitude and duration of annual extreme flows } \\
\hline 90-day minimum & 23 & -12 & -24 \\
\hline 1-day maximum & 63 & -23 & -46 \\
\hline 3-day maximum & 47 & -19 & -37 \\
\hline 7-day maximum & 36 & -15 & -29 \\
\hline 30-day maximum & 27 & -13 & -24 \\
\hline 90-day maximum & 25 & -12 & -24 \\
\hline Number of zero days & -6 & 4 & 9 \\
\hline \multicolumn{4}{|c|}{ Frequency and duration of high and low pulses } \\
\hline Low pulse count & 19 & 0 & 0 \\
\hline Low pulse duration & -12 & 2 & 2 \\
\hline High pulse count & 26 & -16 & -22 \\
\hline High pulse duration & 12 & -2 & -26 \\
\hline
\end{tabular}

P1: $20 \%$ increase in precipitation

P2: $10 \%$ decrease in precipitation

P3: $20 \%$ decrease in precipitation

numbers of high and low pulse flows having short durations, whereas the base scenario and extensive agriculture scenarios have fewer numbers of low and high pulse flows with longer durations.

The IHA parameters for the base scenario and the climate change scenarios are presented in Table 7. The IHA analysis of changes in precipitation conditions indicates a direct relationship between different flow conditions and precipitation magnitudes. It shows an increase in the annual flows with increase in precipitation values and vice versa. The mean annual flows decreased by 10 and $25 \%$ in parallel to 10 and $20 \%$ decrease in precipitation, respectively. A $20 \%$ increase in precipitation resulted in an increase by $25 \%$ in the mean annual flow. Similar trends were observed for the mean monthly flows that increased with an increase in precipitation and decreased with a 
decrease in precipitation; however, the increase in flows seems to be slightly more than an increase in the precipitation. However, it is important to note the changes in the duration of low pulses for different precipitation condition scenarios. The duration of low flow pulses decreased by $12 \%$ due to an increase in precipitation by $20 \%$, while the duration of low pulses increased by $2 \%$ due to a 10 and $20 \%$ decrease in precipitation. The impact of increase in the precipitation on extreme flow conditions is more pronounced than the decrease in precipitation. There is a $36 \%$ increase in the 7-day maximum flow due to a $20 \%$ increase in precipitation as compared to a $29 \%$ decrease due to a $20 \%$ decrease in precipitation. The number of zero flow days is decreased by $6 \%$ due to an increase in the precipitation compared with a $9 \%$ increase due to a $20 \%$ decrease in the precipitation.

These statistics are important considerations for flow management in the stream to sustain the natural habitats of native species as well as flows to the Koycegiz Lake. A shift toward further tourism will increase impervious surfaces in the watershed that will raise runoff with an increase in the magnitude, duration, and frequency of extreme flows. To mitigate the adverse effects on fisheries and ecological health of the stream and the lake-lagoon system, decision makers must provide resources for erosion control, nutrient management, and habitat conservation in the watershed. Similarly, under drought conditions, the crop patterns may be modified according to the hydrologic regime characteristics to avert water shortages for the integrity of stream and lake-lagoon ecosystems.

\section{Conclusion}

The effects of land-use and climate change scenario were analyzed on the hydrologic regime in the Koycegiz Watershed using a HSPF. This analysis is necessary to understand the behavior of different components of the hydrologic regime and the pattern of pollutant and sediment loadings within the watershed. The results show that potential land-use changes and climate variability in the watershed will significantly modify the hydrologic regime of the Namnam Stream causing profound impacts on the three main economic and livelihood functions in the watershed namely agriculture, fisheries, and tourism. Based on the results of the analysis, it is important that the current status of the watershed should be maintained to regulate the equilibrium of important watershed functions without endangering the essential ecosystem services of this vulnerable system. Furthermore, suitable best management practices should be adopted in decision making to increase the resilience of the watershed functions in the wake of potential climate variability.

The representations of the climate change and land-use change scenarios were created to understand the individual impacts of each phenomenon. However, these phenomena seldom happen in isolation from each other. Most often land-use change is a precursor to the impacts of climate change. Furthermore, changes in precipitation is one of the impacts of climate change that may also involve significant changes in the temperatures affecting multiple terrestrial and atmospheric processes such as changes in evapotranspiration rates, humidity, and soil moisture. The scope of this modeling study and the limited availability of data and resources prohibited the inclusion of such complex phenomena, and as such constitute limitations of this study.

Nevertheless, the results put forth an example of watershed model simulation for quantification of changes in the hydrology and land uses within the watershed. This approach enables decision makers and natural resource managers to forecast effects of potential changes in the watershed due to anthropogenic or natural activities. This attempt to quantify the potential effects of climate change and land-use modifications into a decision support framework will enhance development of IWM plans for other ecologically significant watersheds in Turkey.

Acknowledgments This work was supported in part by the US National Science Foundation under the Idaho NSF EPSCoR grant EPS 0814387. Any opinions, findings, and conclusions or recommendations expressed in this material are those of the authors and do not necessarily reflect the views of the National Science Foundation.

\section{References}

Akin S, Buhan E, Winemiller KO, Yilmaz H (2005) Fish assemblage structure of Koycegiz Lagoon Estuary, Turkey: spatial and temporal distribution patterns in relation to environmental variation. Estuar Coast Shelf Sci 64:671-684

Al-Abed N, Al-Sharif M (2008) Hydrological modeling of Zarqa River Basin-Jordan using the Hydrological Simulation Program-FORTRAN (HSPF) model. Water Resour Manage 22(9):1203-1220

Albek M, Ogutveren UB, Albek E (2004) Hydrological modeling of Seydi Suyu watershed (Turkey) with HSPF. J Hydrol 285:260-271

Ames DP, Michaelis CD, Anselmo A, Chen L, Dunsford H (2008) MapWindow GIS. In: Shekhar S, Xiong H (eds) Encyclopedia of GIS. Springer, New York, pp 633-634

Arp CD, Gooseff MN, Baker MA, Wurtsbaugh W (2006) Surfacewater hydrodynamics and regimes of a small mountain streamlake ecosystem. J Hydrol 329(3-4):500-513

ASCE Task Committee on Definition of Criteria for Evaluation of Watershed Models of the Watershed Management Committee Irrigation and Drainage Division (1993) Criteria for evaluation of watershed models. J Irrig Drain Eng 119(3):429-442 
Bach SJ, McAllister TA, Veira DM, Gannon VPJ, Holley RA (2002) Transmission and control of Escherichia coli O157: H7-a review. Canadian J Anim Sci 82:475-490

Baloch MA, Tanik A (2008) Development of an integrated watershed management strategy for resource conservation in Balochistan Province of Pakistan. Desalination 226(1/3):38-46

Baloch MA, Tanik A (2009) Watershed modeling: application of BASINS for the delineation and characterization of Namnam watershed. Istanbul Tech Univ $\mathrm{J}$ Water Pollut Control 19(1-2):85-97 (In Turkish)

Baloch MA, Ames DP, Tanik A (2011) Application of BASINS/ HSPF in the Koycegiz-Dalyan watershed in Turkey: a developing country case study in watershed modeling. In: Brebbia CA (ed) WIT transactions on ecology, the environment, vol 146. Wessex Institute of Technology, UK, p 416

Bates BC, Kundzewicz ZW, Wu S, Palutikof JP (Eds) (2008) Climate change and water. Technical paper of the intergovernmental panel on climate change, IPCC Secretariat, Geneva, p 210

Cheng SJ, Wang RY (2002) An approach for evaluating the hydrological effects of urbanization and its application. Hydrol Process 16(7):1403-1418

Choi W (2008) Catchment-scale hydrological response to climateland-use combined scenarios: a case study for the Kishwaukee River basin Illinois. Phys Geograp 29(1):79-99

Choi W, Deal BM (2008) Assessing hydrological impact of potential land-use change through hydrological and land-use change modeling for the Kishwaukee River basin (USA). J Environ Manage 88(4):1119-1130

Choi W, Rasmussen PF, Moore AR, Kim SJ (2009) Simulating streamflow response to climate scenarios in central Canada using a simple statistical downscaling method. Clim Res 40(1):89-102

Costa MH, Botta A, Cardille JA (2003) Effects of large-scale changes in land cover on the discharge of the Tocantins River, Southeastern Amazonia. J Hydrol 283(1-4):206-217

Dore MHI (2005) Climate change and changes in global precipitation patterns: what do we know? Environ Int 31:1167-1181

Durdu OF (2010) Effects of climate change on water resources of the Buyuk Menderes River Basin, western Turkey. Turkish J Agri For 34:319-332

Erturk A, Alganci U, Tanik A, Seker DZ (2012) Determination of land-use dynamics in a lagoon watershed by remotely sensed data. Fresenius Environ Bull 21(10a):3052-3058

Evans JP (2009) $21^{\text {st }}$ century climate change in the Middle East. Clim Change 92:417-432

Fujihara Y, Tanaka K, Watanabe T, Nagano T, Kojiri T (2008) Assessing the impacts of climate change on the water resources of the Seyhan River Basin in Turkey: use of dynamically downscaled data for hydrologic simulations. J Hydrol 353:33-48

Goncu S, Albek E (2007) Modeling the effects of climate change on different land-uses. Water Sci Technol 56(1):131-138

Guner A, Vural M, Duman H, Donmez AA, Sagban H (1996) The flora of the Koycegiz-Dalyan specially protected area (MuglaTurkey). Turkish J Bot 20(4):329-371

Gurel M, Tanik A, Ertürk A, Dogan E, Okus E, Seker DZ, Ekdal A, Yüceil K, Tümay AB, Karakaya N, Baykal BB, Gonenc IE (2005) Koycegiz-Dalyan Lagoon: a case study for sustainable use and development. In: Gonenc IE, Wolflin J (eds) Coastal lagoons: ecosystem processes, and modeling for sustainable use and development. CRC Press, Boca Raton

Hemming D, Buontempo C, Burke E, Collins M, Kaye N (2010) How uncertain are climate model projections of water availability indicators across the Middle East? Philos Trans Royal Soc Math Phys Eng Sci 368(1931):5117-5135

Hunter HM, Walton RS (2008) Land-use effects on fluxes of suspended sediment, nitrogen and phosphorus from a river catchment of the Great Barrier Reef, Australia. J Hydrol 356:131-146

Im SJ, Brannan KM, Mostaghimi S (2003) Simulating hydrologic and water quality impacts in an urbanizing watershed. J Am Water Resour Assoc 39:1465-1479

Jones KB, Neale AC, Nash MS, Van Remortel RD, Wickham JD, Riitters KH, O’Neill RV (2001) Predicting nutrient and sediment loadings to streams from landscape metrics: a multiple watershed study from the United States Mid-Atlantic Region. Landscape Ecol 16:301-312

Krasovskaia I, Gottschalk L (2002) River flow regimes in a changing climate. Hydrol Sci J 47(4):597-609

Kuvan Y (2010) Mass tourism development and deforestation in Turkey. Anatolia Int J Tour Hosp Res 21(1):155-168

Lumb AM, McCammon RB, Kittle JL Jr. (1994) Users' manual for an expert system (HSPEXP) for calibration of the Hydrologic Simulation Program-FORTRAN: USGS Water-Resources Investigations Report 94-4168

Mariotti A, Zeng N, Yoon JH, Artale V, Navarra A, Alpert P, Li LZX (2008) Mediterranean water cycle changes: transition to drier 21 st century conditions in observations and CMIP3 simulations. Environ Res Lett 3(4):044001

Martinec J, Rango A (1989) Merits of statistical criteria for the performance of hydrological models. Water Resour Bull 25(2):421-432

Olden JD, Poff NL (2003) Redundancy and the choice of hydrologic indices for characterizing streamflow regimes. River Res Appl 19:101-121

Onol B, Semazzi FHM (2009) Regionalization of climate change simulations over Eastern Mediterranean. J Clim 22:1944-1961

Ozkul S (2009) Assessment of climate change effects in aegean river basins: the case of Gediz and Buyuk menderes basins. Clim Change 97(1-2):253-283

Poff NL, Bledsoe BP, Cuhaciyan CO (2006) Hydrologic variation with land-use across the contiguous United States: geomorphic and ecological consequences for stream ecosystems. Geomorphology 79:264-285

Ribarova I, Niniv P, Copper D (2008) Modeling nutrient pollution during a first flood event using HSPF software: Iskar River case study, Bulgaria. Ecol Model 211:241-246

Richter W (1997) Restoring ecosystems. Science 278:997-998

Richter BD, Baumgartner JV, Powell J, Braun DP (1996) A method for assessing hydrologic alteration within ecosystems. Conserv Biol 10: 1163-1174. http://www.tufts.edu/water/pdf/iha_meth.pdf

Saleh A, Du B (2004) Evaluation of SWAT and HSPF within BASINS program for the Upper North Bosque River Watershed in Central Texas. Trans. ASAE 47(4):1039-1049

Saygili F, Yigit N, Bulut S (2011) The spatial and temporal distributions of waterbirds in Lakes Akşehir-Eber and Lake Köyceğiz in western Anatolia, Turkey—a comparative analysis. Turk J Zool 35(4):467-480

Shirinian-Orlando AA, Uchrin CG (2007) Modeling the hydrology and water quality using BASINS/HSPF for the upper Maurice River watershed, New Jersey. J Environ Sci Heal A 42:289-303

Strunk H (2003) Soil degradation and overland flow as causes of gully erosion on mountain pastures and in forests. Catena 50:185-198

Tayanc M, Im U, Dogruel M, Karaca M (2009) Climate change in Turkey for the last half century. Clim Change 94(3-4):483-502

Tumay AB, Brouwer R (2007) Nonmarket valuation of water quality in a rural transition economy in Turkey applying an a posteriori bid design. Water Resour Res 43(W05436):1-13

Vidal JP, Wade SD (2008) Multimodel projections of catchment-scale precipitation regime. J Hydrol 353:143-158

Xu Z, Godrej AN, Grizzard TJ (2007) The hydrological calibration and validation of a complexly linked watershed reservoir model for the Occoquan watershed, Virginia. J Hydrol 345(3-4):167-183 
Yano T, Aydin M, Haraguchi T (2007) Impact of climate change on irrigation demand and crop growth in a Mediterranean environment of Turkey. Sensors 7(10):2297-2315

Yilmaz F, Barlas M, Yorulmaz B, Ozdemir N (2006) A taxonomical study on the inland water fishes of Muğla E.U. J Fisch Aquat Sci 23(1-2):27-30
Yuceil K, Baloch MA, Gonenc E, Tanik A (2007) Development of a model support system for watershed modeling: a case study from Turkey. Clean: Soil, Air, Water 35:638-644 